УДК 004.71

\author{
Pavlo Galkin (Senior Lecturer) \\ Kharkiv National University of Radioelectronics (Ukraine) \\ E-mail: pavlo.halkin@nure.ua,galkinletter@ukr.net
}

\title{
ADAPTIVE CONCEPTS AND OPTIMIZATION APPROACH TO DESIGN OF TESTBENCHES AND NODES FOR WIRELESS SENSOR NETWORKS
}

The object of the research is nodes and testbenches for wireless sensor networks. The article analyzes the requirements for a wireless sensor network node and testbenche. Goal of the research is develop adaptive concept and optimization approach to design of testbenches and nodes for wireless sensor networks. The hardware components for building test platform for wireless sensor networks were proposed. Also test platform for wireless sensor networks was developed as printed circuit board. As a result proposed solution can use for prototype, build and scale wireless sensor network. In node structures for wireless sensor network proposed use modules CC2530. Also peripherals capabilities of CC2530 were analyzed. As one of optimization approach to designing wireless sensor network given the structure of node. Also given report about difference in concept to designing nodes and uses areas. In conclusion, the developed approaches can be used for any application of the wireless sensor network.

Ключові слова: Adaptive Concept; CC2530; Design of Testbenches; Design of Nodes; Internet of Things; Software and Hardware Test Platform; Optimization Approach; Wireless Sensor Network; Wireless Sensor Design; ZigBee

DOI: $10.31474 / 2075-4272-2019-1-32-59-70$

Introduction. The Wireless sensor network (WSN) is a self-organizing network based on data-centric. One of the advantages of WSN is its ability to function in harsh environments in which contemporary human-in-the-loop monitoring schemes are risky, inefficient and sometimes infeasible [1]. Energy efficiency approach is important for long life time of network and collection data [2]. As for the hardware, it is depends from field of WSN uses. For example in article [3] proposed hardware node uses a STM32F103VET6 as a processing core, and a WLK01L39 RF chip is used in wireless communication module, while the sensor module is composed of the air temperature and humidity sensor, light intensity sensor and soil moisture sensor.

In research [4] proposed a water pollution remote monitoring system based on Wireless Sensor Network is proposed for the protecting the ecological environment of water resources. The low power consumption $\mathrm{C} 8051 \mathrm{~F} 930$ is as the controller, the $\mathrm{pH}$ glass composite electrode sensors are used to measure $\mathrm{pH}, \mathrm{pH}$ sensors collect the signal is processed, converted and disposed according to the potential measuring principle of $\mathrm{pH}$ composite electrode. Field data is transmitted and converted by the low power consumption wireless RF transceiver module Si4432, the water pollution of river basin is monitored by remote real-time. In article [5] proposed solution for node navigation consists in two levels implementation: a low level section (the sensory level) and a high level section (the fusion data level). The paper [6] propose a microcontroller based anti poaching system employing WSN technology, which is capable of detecting theft by monitoring the vibrations produced by the cutting of trees/branches using a 3 axis MEMS accelerometer. A low power MSP430F5529 microcontroller is used along with Xbee RF modules based on IEEE 802.15.4 Zigbee standards to communicate to a central server from a remote place. The article [7] presents analysis of single-board computers for Internet of Things solutions. Paper presents analysis the possibility of application distribution solution by ESP8266 and CC2530 as WSN nodes. In 
article [8] present the communication model between ZigBee network and industrial network. The paper [9] presents the design of an efficient energy harvesting system for energizing wireless sensor nodes using the electromagnetic radiation from cell towers in the CDMA and GSM bands. In article [10] demonstrates the application of an integrated Wireless Sensors Network (WSN) system associated with GPS and GIS to achieve the goal of Smart Agriculture. Therefore, it is quite difficult to design a sensor network node so that it satisfies the necessary criteria for optimality. If such a node is also used for testing and training, then additional requirements for the construction will be propose.

Important problem fro WSN is energy efficient algorithms of data collation. A number of algorithms now exist for using model-based prediction at the sensor node of a wireless sensor network (WSN) to enable a dramatic reduction in transmission rates, and thus save energy at the sensor node [11]. For example in order to effectively reduce the power consumption of WSN node in agricultural greenhouses, on the basis of considering the actual needs of the agricultural greenhouse WSN node, the low power consumption design of WSN node was studied [12].

The paper [13] introduces the basic structure of wireless sensor network node based on ARM, and it delivers a detailed analysis on the operating features and the CC2480 hardware interface of the ZigBee processor, what's more, it specifically talks about the implementation of the Wince driver of WSN nodes. Good example for build educational kit shown in paper [14]. Model for reducing energy consumption in wireless sensor network is also presented in paper [15]. Appropriate node management of networks in the limited resources of the wireless sensor network for effectively control the energy of networks is one of the key points in research on wireless sensor networks [16].

The paper [17] presents a wireless sensor network (WSN) for onboard monitoring of railway freight wagons, in which all the network nodes are energetically autonomous. Unlike the usual energy-harvesting WSNs, here it is proposed to supply not only the sensor nodes but also the sink node by means of an energy harvester, in order to realize independent networks for each wagon. This choice allows the overcoming of several issues related to a single network for the whole train, but it requires a significant reduction of the energy consumption of the power-hungry sink node. In order to reduce the energy consumption to values sustainable by energy harvesters without penalizing the quality of service, this paper proposes a bi-periodic communication scheme for the local wireless transmission, a dynamic management of the GPS receiver, and a consumption model of the GPRS transceiver, which allows an optimized management of the sleep modes.

Network reliability has vital importance for designing wireless sensor networks [18]. In paper [19] propose a new architectural model for WSNnodes (and its complete design-flow from C downto synthe-sizable VHDL) based on the notion of micro-tasks. Alternative approach for energy efficient [20] uses utilizing energy form the surroundings, small amounts of power can be harvested from wind, solar radiation and stress sources. Energy harvested is converted to battery potential via a converter. In contradiction in article [21] is approved WSNs are hardly in need of an additional source of power other than the normally used batteries, to increase the lifetime considerably. Heterogeneous sensor networks have been proposed to address some fundamental limits and performance issues present in homogeneous Wireless Sensor Networks (WSNs) [22]. Therefore, after analyzing the developed and designed nodes, can define several research tasks:

Two specifics of CPLD are used in the proposed method [6,7]:

- optimize the structure of the node;

- selection of chip for WSN node;

- peripheral requirements development;

- design requirements for testbench;

- analysis of the requirements for the testbench.

Concepts of Node for Wireless Sensor Network. At the moment, there are two basic solutions for constructing ZigBee nodes for wireless sensor networks. In the first case, the 
developer is encouraged to construct the hardware unit independently, using different microprocessors supporting the IEEE 802.15.4 radio interface.

The radio transceiver in IEEE 802.15.4 complies only with the functions of receiving and transmitting information over a radio channel and does not contain software that implements the ZigBee protocol stack. The software implementation of the ZigBee stack relies on an external microcontroller to which the transceiver chip connects to one of the standard interfaces, such as a serial peripheral interface (SPI) or a parallel interface. Additionally, the transceiver requires a bunch, which includes an antenna, a quartz resonator, as well as a small number of passive components. The use of such SoC (Systems on the crystal) or SiP (Integrated hybrid chips) performs all the functions for working with ZigBee as WSN node and a microcontroller to perform a user program, though it will be less energy efficient, but in turn will be able to provide greater flexibility to execute this program in terms of Input/Output, external interfaces, or have any specific functions. This option is not the most economical in terms of the cost of chips, but it does not require much effort in design development. In the case of using a platform in a single body (PiP), the design task in general consists only in the organization of the binding of this chip. The digamma of structure chip is shown on (Fig. 1).

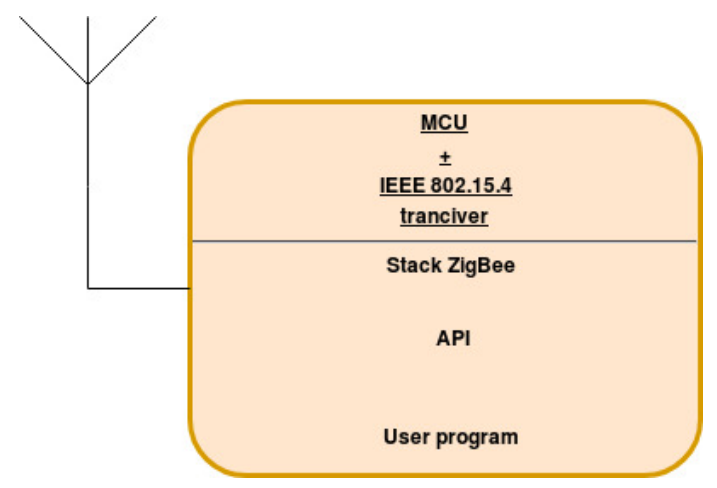

Figure 1 - This is a digamma of structure WSN node in one System on the crystal

Another version with separate microcontroller with user program and radio transceiver. In this case the microcontroller has enough resources not only for realization the main functions of the program, but also the ZigBee stack. In this case, the chip The IEEE 802.15.4 radio transceiver interfaces with the base processor per means SPI interface. This structure is shown on (Fig. 2).

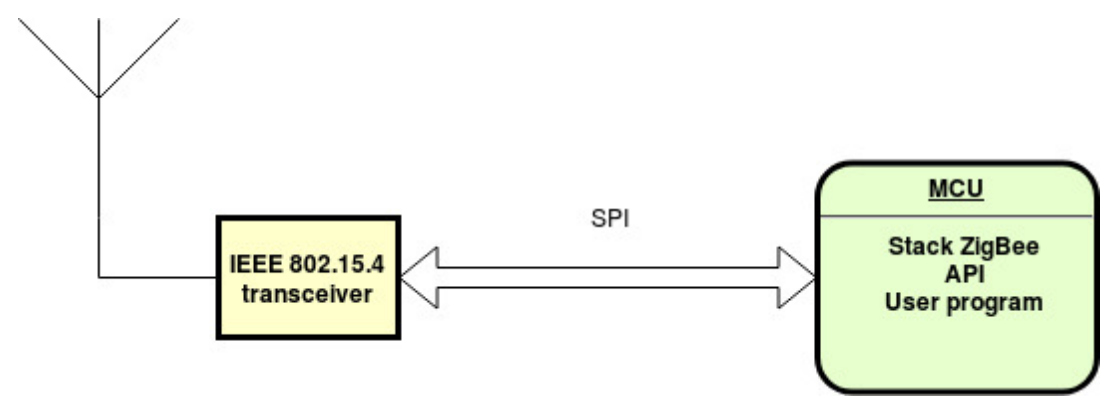

Figure 2 - This is a digamma of WSN node with separate radio transceiver and microcontroller with user program

The structure shown on (Fig. 3). differs only in that there two microcontrollers are used: the first to implement the ZigBee stack, and the other to execute the user program, the data exchange is also carried out through the SPI. This option increases the overall power consumption. 


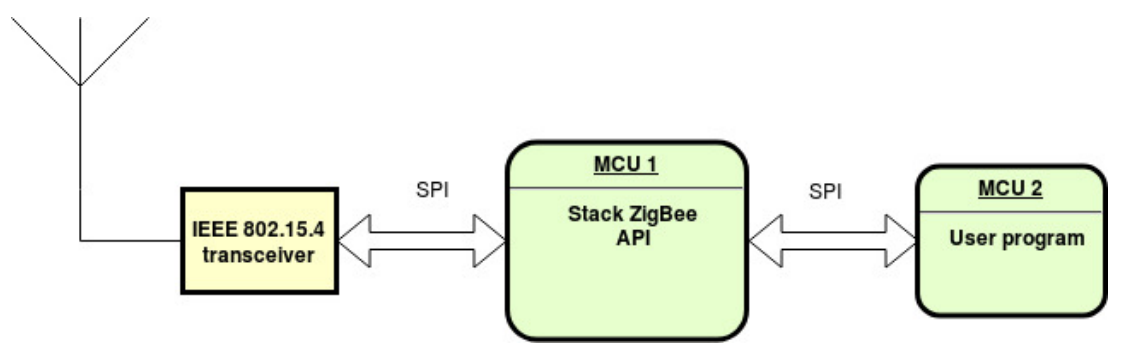

Figure 3 - This is a digamma of structure WSN node with two MCU and one transceiver

The closest case to the implementation of the one system on a chip is the system shown in Figure 4, where separate microcontroller is used for user program.

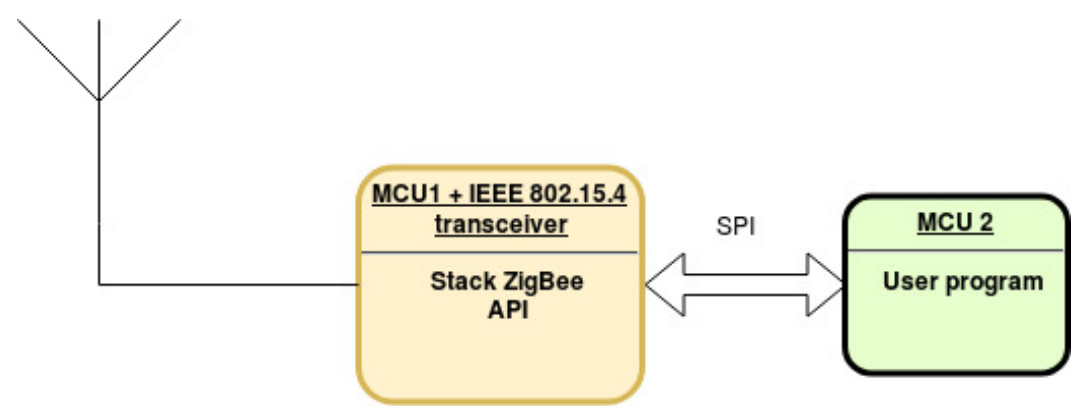

Figure 4 - This is digamma of structure WSN node with one MCU for user program and one MCU with transceiver

After considering the peculiarities of the structure the node of wireless sensor networks, it should be noted difference between $\mathrm{SiP}$ and $\mathrm{SoC}$ approaches. Integrated hybrid chips, which combine in one case crystals of the "classic" radio transmitter and general purpose microcontroller. This solution allows you to place the ZigBee software stack directly in the built-in microcontroller memory and thereby significantly reduce load on an external microcontroller, which provides solution to the tasks of a particular application. These microcircuits require a minimum strap, including an antenna. Systems on the crystal - this type of chip actually replicate the capabilities of $\mathrm{SiP}$, but unlike them and the transmitter receiver, and built-in the microcontroller is executed on one crystal. Some firms, such as Texas Instruments, called such crystals ZigBee processors. They interact with the external controller of the application in one of the standard interfaces (SPI, Universal Asynchronous Receiver (UART)) and allow loading in memory of network protocols of different complexity depending on the predicted the complexity and structure of the implemented network.

Therefore, we can conclude that WSN node in one SoC it is first step for optimization energy consumption of node and consequently, longer life time all network.

Analysis of Existing Boards for Wireless Sensor Networks. The use of ready-made modules is the easiest way to start working with WSN, since it does not require its own development, only need to select the module with the required number of ports, the required data interfaces and related parameters. Such modules are often installed directly on the board with the necessary operating equipment, sensors or simply with the output of ports of (Fig. 5). Company developers of these modules usually also make additional modules with different input / output devices, sensors and other related equipment. In addition, there are additional expansion cards (shield) designed to power the module itself, port output to the connectors containing LEDs reflect the state of the module and additional buttons. 


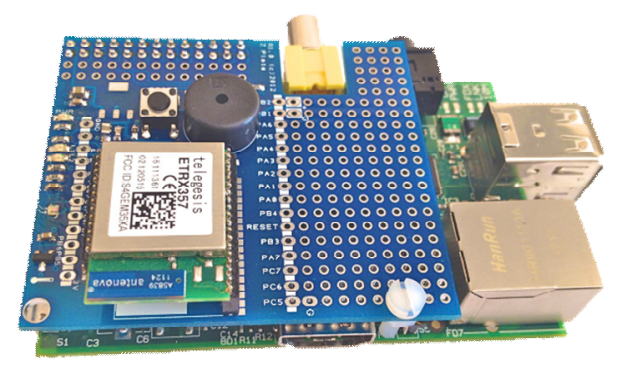

Figure 5 - Board for Wireless Sensor Networks

As an example of a debugging board for the ZigBee module you can consider the ZigBee CC2530 Sensor (Fig. 6), from the company Texas Instruments which is designed for the modules CC2530EM.

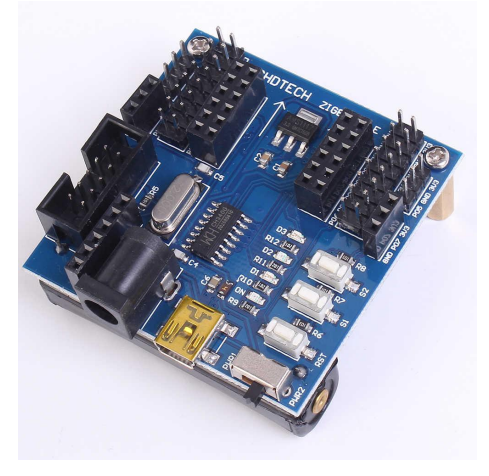

Figure 6 - Test board CC2530 Sensor

The paper [23] propose a microcontroller based anti poaching system employing WSN technology, which is capable of detecting theft by monitoring the vibrations produced by the cutting of trees/branches using a 3 axis MEMS accelerometer. A low power MSP430F5529 microcontroller is used along with Xbee RF modules based on IEEE 802.15.4 Zigbee standards to communicate to a central server from a remote place. Xbee board shown on (Fig. 7).

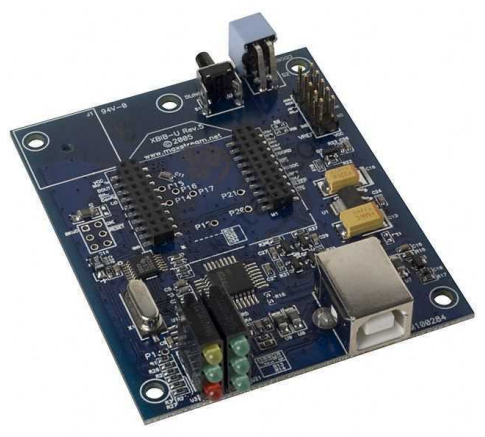

Figure 7 - Xbee board

In manuscript [24] present a survey of designs and implementations of research sensor nodes that rely on FPGAs, either based upon standalone platforms or as a combination of microcontroller and FPGA. Numerous applications of wireless sensor networks are constrained by the limited battery power of the sensors. The power consumption of processors and microcontrollers could be scaled down dramatically with the new advances in microelectronics [25]. 
In general, designing of a node is reduced to the choice of a controlling microcontroller or immediately a radio receiver in a single module. Further, after study of periphery and the design of the device as a whole.

Optimization Approach for Structure of Nodes. The first stage of optimizing the collection of information can begin with the optimization of the structure of the wireless sulfur network node. Next step is clustering of WSN. Cluster tree topology of typical WSN show on Figure. 8. When forming clusters, coordinator of wireless sensor network sends a broadcast transmit to all neighboring nodes. Then each nodes send request permission to connect the cluster. If the WSN coordinator allows, then a connection is approve with the node of sensor network, which starts by schedule or other method for sending data and to connect other nodes.

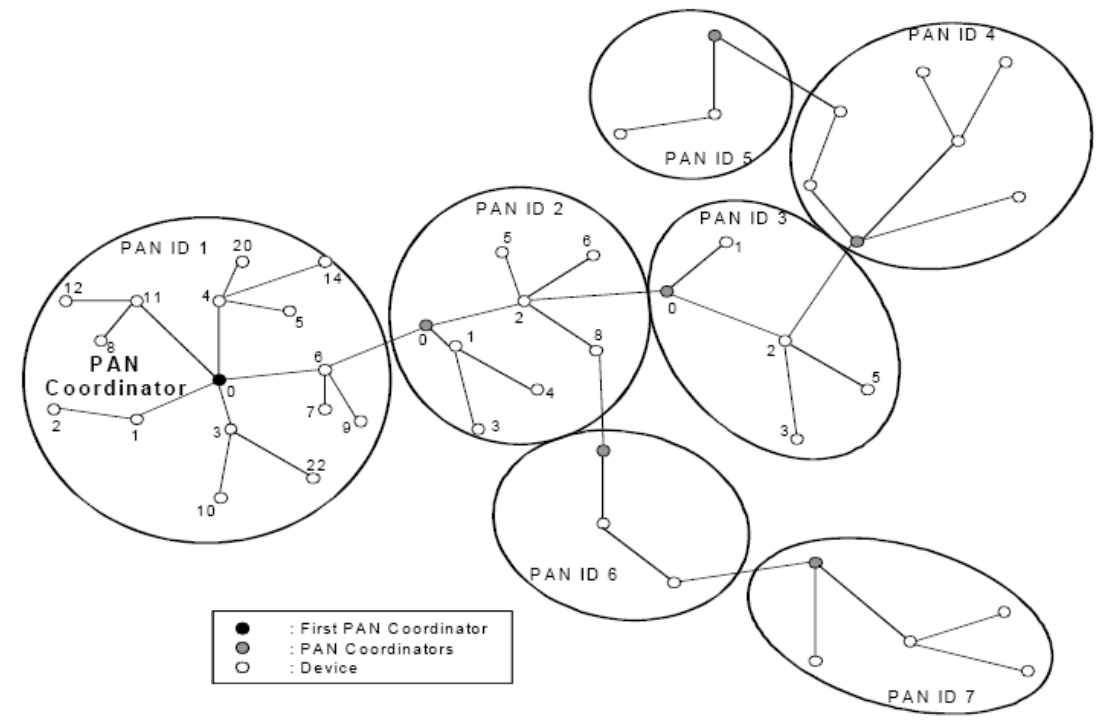

Figure 8 - Cluster tree topology of typical WSN

Also possible use approach as model-based design of IoT/WSN Nodes [26], low-energy data processing architecture [27], used Lora for one of nodes [28]. Wireless Sensor Networks are moving out of the laboratory and into the field. For a number of reasons there is often a need to update sensor node software, or node configuration, after deployment. The need for over-the-air updates is driven both by the scale of deployments, and by the remoteness and inaccessibility of sensor nodes [29]. In wireless sensor networks, building energy-efficient systems is one of the major challenges. In such networks, nodes are usually supplied by low power and small batteries [30]. Also possible use copy-at-neighbouring-node retransmission strategy for improved wireless sensor network lifetime and reliability [31]. Other approaches to the design of nodes were considered in the research [32-37].

There are many different modules to implement ZigBee networks. Each of them has its own features, both in terms of the hardware part and in terms of software in the form of various environments for working with these modules. There are various modules based on the SoC CC2530 [2, 7], in essence they are a board that hosts the CC2530 itself, an external quartz resonator, several passive components, an antenna connector (or built-in antenna) and outputs for connecting to other devices. The typical node of wireless sensor network can be constructed using a chip CC2530. This transceiver can be ready for prototyping by PCB board-module (Fig. 9). 


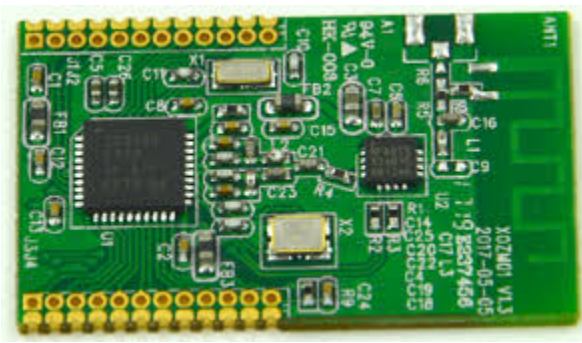

Figure 9 - PCB board-module base on chip CC2530 and ready for prototype

The module CC2530 can serve as coordinator, router, and end device. It combines flexible hardware capabilities, a sufficient range of work and, with all this, has excellent energy efficiency and low price performance. include:

Design Requirements for Testbench. Development testbench vase on CC2530 must

- optimize the structure of the node;

- selection of chip for WSN node;

- sensors of illumination;

- voltage regulator;

- power connectors, USB, JTAG, LCD;

- battery compartment

- UART / USB converter;

- indication elements in the form of LEDs;

- controls in the form of buttons, contact switches, elements of external switching;

- passive elements in the form of resistors, capacitors.

The wiring diagram of the CC2530 is shown in (Fig. 10). As can be seen in the figure, the CC2530 chip requires a very small number of external components, which greatly simplifies the development of a new product. The microcircuit is suitable for use in a variety of applications. For this, it is integrated as standard microcontroller peripherals: 8/16 bit timers; watchdog; ADC two USART modules with support for SPI and UART protocols; I / O ports (21 lines: 19x4 + 2x20 mA) and specialized: MAC timer (defined by the IEEE 802.15.4 standard), hardware support unit for the network protocol CSMA / CA, as well as random number generator and data encryption / decryption accelerator AES algorithm using a 128-bit key.

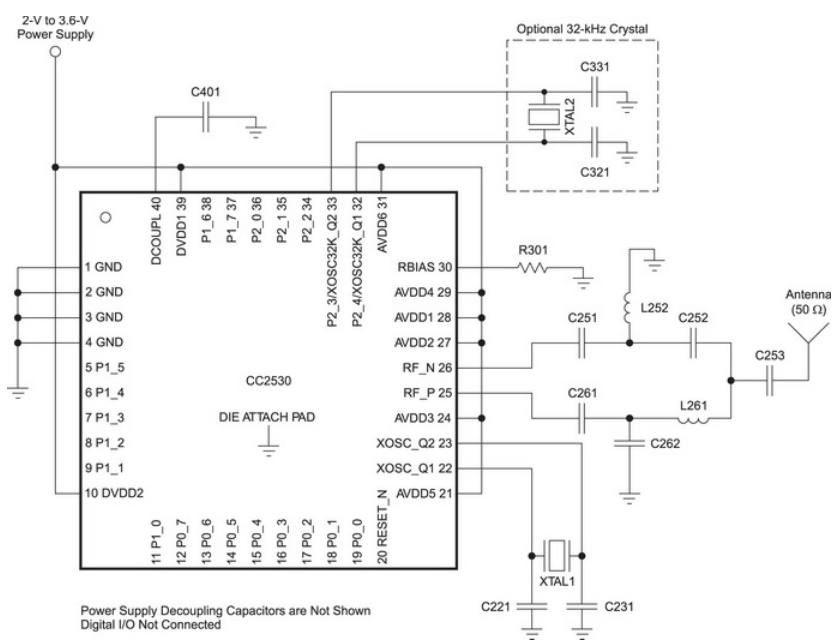

Figure 10 - PCB board-module base on chip CC2530 and ready for prototype 
The scheme of switching on devices depends on the switching of the contact switches on the rack leads, which gives the possibility for various tests of module CC2530. The main element of the circuit is a microcontroller, which is commutated through the contact rails and performs basic functions of controlling the device elements. The microcontroller's power supply must be via a voltage regulator that provides a stable voltage of $3.3 \mathrm{~V}$ for the entire device. The data transmission is carried out by means of signaling from different devices on the input lines of the CC2530 microcontroller through an appropriate connector. As sensors of lightning act photoresistors that are connected to the terminals of the chip as a voltage divider. Data from the sensors comes to the ports of the microcontroller.

Design Structure and PCB of Testbench. As a result of the analysis of the requirements for the testbench, the structure was developed, (Fig. 11). Requirements to ensure the technologic design of the node are reduced to the implementation of a complex factor of productivity at the level of 0.5. It takes into account such parameters as availability, interchange ability, provision of spare particles, that is, elements included in the design, should be available for inspection and replacement without the prior removal of other parts. It must be possible to install the extracted parts on the table during repair in a convenient position.

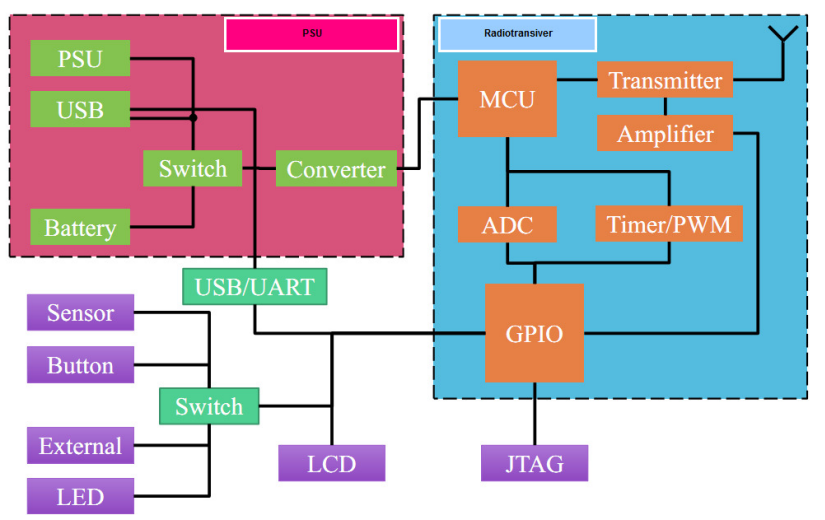

Figure 11 - PCB board-module base on chip CC2530 and ready for prototype

A simple arrangement of the elements was carried out. Also a PCB was developed, (Fig 12). PCB is ready for manufacture.
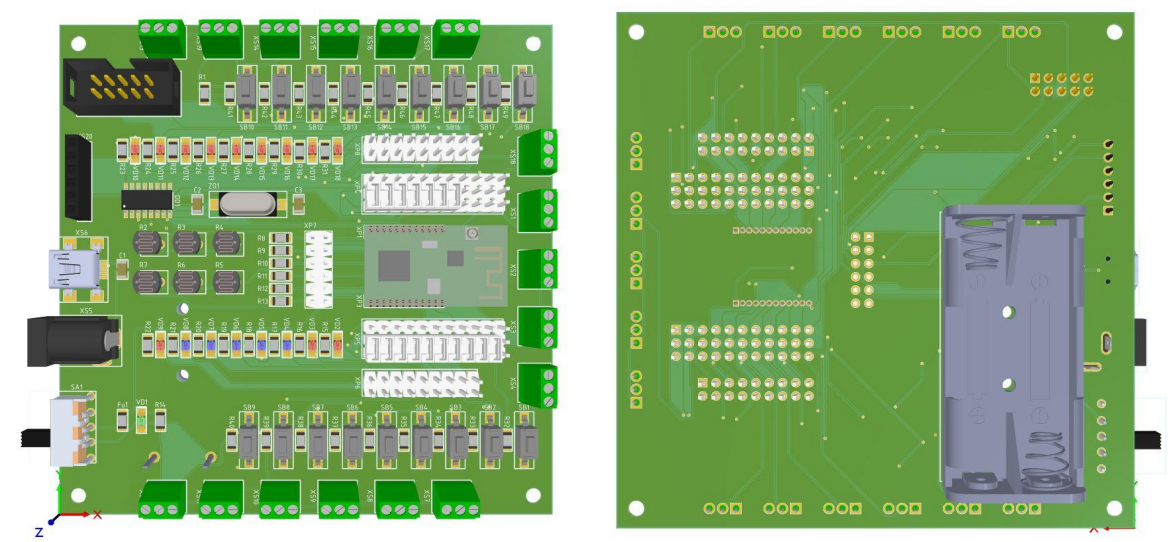

Figure 12 - PCB Design of testbenches and nodes for wireless sensor networks (a) Top view; (b) Bottom view.

As a result of the reasech, the testbecnh for the wireless sensor network was received, which has the following characteristics:

- 17 independent GPIO; 
- 17 control buttons;

- 17 light indicators;

- 6 sensors of illumination;

- 5 independent PWM channels;

- place under the LCD monitor;

- dimensions $100 \mathrm{~mm}$ x $100 \mathrm{~mm}$ x $30.5 \mathrm{~mm}$;

- weight $69.28 \mathrm{~g}$.

Results. As a result of the research, the testbench for the wireless sensor network was developed. Also as a result of the analysis of the requirements for the testbench, the structure was developed the testbench for the wireless sensor network and it is can use for other resechers projects.

Discussion. The object of the research was the hardware component for building a test platform for wireless sensor networks. The aim of the research was to develop a software and hardware test platform for wireless sensor networks.

As a result of the analysis, the node structures, wireless sensor network modules, CC2530 peripherals were analyzed. A module based on the CC2530 PA was chosen as the hardware. As elements of the periphery, the following elements were chosen:

- optimize the structure of the node;

- LEDs;

- push buttons;

- photoresistors;

- exit to the LCD display

- exits to the outer periphery

A contact switch is selected to switch between the peripheral elements.

The proposed approaches can be applied in the development of nodes built on another transceiver. Further research will be directed at detailing nodes of WSN.

Conclusions. The during of research, it was considered optimize the structure of the node, selection of chip for wireless sensor network node and discussion about peripheral requirements development. A module based on the CC2530 PA was chosen as the hardware. In article was noted that optimize of structure the wireless sensor network node as one of approach to designing a wireless sensor network with long life cycle. As a result of the analysis of the requirements for the testbench, the structure was developed. As a result of the research, the testbench for the wireless sensor network was developed.

Acknowledgments: Thanks to my Wife and my Kids for their patience while working on the article. Also, thanks to my graduate students Ivan Burgh and Vinokurov Adeksandr for supporting the prototyping of the printed circuit board.

\section{References}

1. Daozong, S.; Weixing, W.; Jianqing L.; Zuanhui L.; Design of WSN nodes and network performance analysis in a tea plantation. IET International Conference on Wireless Sensor Network 2010 (IET-WSN 2010), Beijing, 2010, 144-147. [CrossRef]

2. Galkin, P.; IEEE, Analysis Models of Collection Data in Wireless Sensor Networks. 2016 Third International Scientific-Practical Conference Problems of Infocommunications Science and Technology (Pic S\&t) 2016, 233-236. [CrossRef]

3. Chen, H. Q.; Sun, B. X.; Wang, W. X.; Weng, J. P.; Tie, F. L.; Ieee, Design of a WSN Node for Rice Field based on Hybrid Antenna. 2017; p 276-280. [CrossRef]

4. Chen, Z. J.; Guo, Q. Y.; Shi, Z., Design of WSN node for water pollution remote monitoring. Telecommunication Systems 2013, 53 (1), 155-162. [CrossRef]

5. Dobkescu, R.; Popescu, D.; Nicolae, M., Design of a Modular Node for Tracking, Localization 
and Data Acquisition for WSN Applications. In Proceedings of the 4th Wseas International Conference on Remote Sensing, Misra, S. C.; Revetria, R.; Sztandera, L. M.; Iliescu, M.; Zaharim, A.; Parsiani, H., Eds. 2008; pp 51-56.

6. Gaikwad, S.; Patil, R.; Khandare, A.; Rai, A.; Ieee, Design WSN Node For Protection Of Forest Trees Against Poaching based on ZigBee. 2015. [CrossRef]

7. Galkin, P.; Golovkina, L.; Klyuchnyk, I.; IEEE, Analysis of Single-Board Computers for IoT and IIoT Solutions in Embedded Control Systems. 2018; p 297-302. [CrossRef]

8. Galkin, P.; IEEE, Interaction Model Design of Zigbee-Gateway between Wireless Sensor Network and Industrial Network. 2017 4th International Scientific-Practical Conference Problems of Infocommunications-Science and Technology (Pic S\&T) 2017, 501-504. [CrossRef]

9. Ghosh, S.; Ghosh, S. K.; Chakrabarty, A., Design of RF Energy Harvesting System for Wireless Sensor Node using Circularly Polarized Monopole Antenna RF energy harvesting system for WSN node using circularly polarized antenna. 2014 9th International Conference on Industrial and Information Systems (Iciis) 2014, 239-+. [CrossRef]

10. Gupta, N.; Gupta, P. P.; Pramanik, P.; Saikia, A.; Sengupta, L.; Bhagat, R. M.; Bhattacharya, N. In Integration of geoinformatics and wireless sensors for smart agriculture in tea, 2nd International Conference on Remote Sensing and Geoinformation of the Environment (RSCy), Paphos, CYPRUS, Apr 07-10; Paphos, CYPRUS, 2014. [CrossRef]

11. Gyamfi, K. S.; Brusey, J.; Gaura, E.; Wilkins, R., Heartbeat design for energy-aware loT: Are your sensors alive? Expert Systems with Applications 2019, 128, 124-139. [CrossRef]

12. Huang, J., Research and Design of Low Power Consumption of WSN Node in Agricultural Greenhouse. In Proceedings of the 2017 7th International Conference on Education, Management, Computer and Society, Jing, W.; Guiran, C.; Huiyu, Z., Eds. 2017; Vol. 61, pp 544-549.

13. Ju, J. W., The Design of WinCE Driver of WSN Nodes Based on ARM. In Mechatronics Engineering, Computing and Information Technology, Xu, X. D.; Li, B.; Lu, Q. M.; Yan, X. Y.; Li, J. L., Eds. 2014; Vol. 556-562, pp 6058-6062. [CrossRef]

14. Langmann, R.; Makarova, Y.; Rojas-Pena, L.; Galkin, P.; Klyuchnik, I.; Voropaeva, V.; Pozepaev, V.; Zinyuk, L.; Skrypyuk, R.; Shaporina, E.; Shaporin, V.; Shapo, V.; Gorb, S.; IEEE, Workshop: The TATU Lab \& Smart Education. In Proceedings of 2016 13th International Conference on Remote Engineering and Virtual Instrumentation (Rev), 2016; pp 400-402. [CrossRef]

15. Galkin, P.; IEEE, Model of Reducing the Power Consumption for Node of Wireless Sensor Network in Embedded Control Systems. 2018; p 252-256. [CrossRef]

16. Li, H. S.; Liu, S. M.; Hu, B., Design of Node Power Management in WSN Based on Ant Colony Algorithm. 2009; p 739-+. [CrossRef]

17. Lo Schiavo, A., Fully Autonomous Wireless Sensor Network for Freight Wagon Monitoring. Ieee Sensors Journal 2016, 16 (24), 9053-9063. [CrossRef]

18. Ozkan, O.; Ermis, M.; Bekmezci, I., Reliable wireless multimedia sensor network design: comparison of hybrid metaheuristics and a matheuristic. Computational \& Applied Mathematics 2019, 38 (3). [CrossRef]

19. Pasha, M. A.; Derrien, S.; Sentieys, O.; Ieee, A Complete Design-Flow for the Generation of Ultra Low-Power WSN Node Architectures Based on Micro-Tasking. In Proceedings of the 47th Design Automation Conference, 2010; pp 693-698. [CrossRef]

20. Qian, H. M.; Sun, P.; Rong, Y. J., Design Proposal of Self-Powered WSN Node for Battle Field Surveillance. In 2012 International Conference on Future Energy, Environment, and Materials, Pt B, Yang, G., Ed. 2012; Vol. 16, pp 753-757. [CrossRef]

21. Rajendran, H.; Ramabadran, R.; Sankararajan, R., Design and Implementation of PV based Energy Harvester for WSN Node with MAIC algorithm. Advances in Electrical and Computer 
Engineering 2015, 15 (2), 109-116. [CrossRef]

22. Ramos, H. S.; Boukerche, A.; Oliveira, A. L. C.; Frery, A. C.; Oliveira, E. M. R.; Loureiro, A. A. F., On the deployment of large-scale wireless sensor networks considering the energy hole problem. Computer Networks 2016, 110, 154-167. [CrossRef]

23. Salunkhe, P. G.; Chaudhari, P. U.; IEEE, Design WSN Node For Protection Of Forest Trees Against Poaching Based MSP430. 2018; p 520-523.

24. Sun, Y.; Li, L.; Luo, H.; Ieee, Design of FPGA-based Multimedia Node for WSN. In 7th International Conference on Wireless Communications, Networking and Mobile Computing (WiCOM). 2011.

25. Varghese, B.; John, N. E.; Sreelal, S.; Gopal, K., Design and development of an RF energy harvesting wireless sensor node (EH-WSN) for aerospace applications. In Proceedings of the 6th International Conference on Advances in Computing and Communications, Mathew, J.; DasKrishna, D.; Jose, J., Eds. 2016; Vol. 93, pp 230-237.

26. Vorapojpisut, S.; Ieee, Model-based Design of IoT/WSN Nodes: Device Driver Implementation. 2018 International Conference on Embedded Systems and Intelligent Technology \& International Conference on Information and Communication Technology for Embedded Systems (Icesit-Icictes) 2018.

27. Walravens, C.; Dehaene, W.; Ieee, Design of a Low-Energy Data Processing Architecture for WSN Nodes. In Design, Automation \& Test in Europe, 2012; pp 570-573.

28. Widodo, S.; Cahya, R. B.; Nasrullah, Y.; Supriyanto, E.; Rubiono, G.; Iop, Design of the Node Coordinator Based on WSN Network as Fisherman Vessel Monitoring System. In International Conference on Frontier of Science and Society, 2018; Vol. 156. [CrossRef]

29. Brown, S.; Sreenan, C.J. Software Updating in Wireless Sensor Networks: A Survey and Lacunae. J. Sens. Actuator Netw. 2013, 2, 717-760. [CrossRef]

30. Ouadou, M.; Zytoune, O.; El Hillali, Y.; Menhaj-Rivenq, A.; Aboutajdine, D. Energy Efficient Hardware and Improved Cluster-Tree Topology for Lifetime Prolongation in ZigBee Sensor Networks. J. Sens. Actuator Netw. 2017, 6, 22. [CrossRef]

31. Yucel, T.; Altin-Kayhan, A., A copy-at-neighbouring-node retransmission strategy for improved wireless sensor network lifetime and reliability. Journal of the Operational Research Society 2019, 70 (7), 1193-1202. [CrossRef]

32. Zhang, B. L.; Gao, F.; Wang, J. H., A Design and Implementation of Power Management for WSN Node Based on Weighted Least Squares Method. 2010; p 73-77.

33. Zhang, L. P.; Yu, Y. L.; Ma, H.; Zhang, Y.; Cao, P., Design of Photovoltaic Power Supply MPPT Circuit for WSN Node Based on Current Observation. International Journal of Online Engineering 2018, 14 (7), 45-61. [CrossRef]

34. Zhang, Z. C.; Meng, M. Q. H.; Wu, F. Q.; Chen, X. J.; Ieee, Design of WSN Node Based on CC2431 Applicable to Lunar Surface Environment. 2009; p 1087-1092.

35. Pal, A.; Nasipuri, A. Distributed Routing and Channel Selection for Multi-Channel Wireless Sensor Networks. J. Sens. Actuator Netw. 2017, 6, 10. [CrossRef]

36. Rodrigues, L.M.; Montez, C.; Budke, G.; Vasques, F.; Portugal, P. Estimating the Lifetime of Wireless Sensor Network Nodes through the Use of Embedded Analytical Battery Models. $J$. Sens. Actuator Netw. 2017, 6, 8. [CrossRef]

37. Niedermeier, M.; He, X.; De Meer, H.; Buschmann, C.; Hartmann, K.; Langmann, B.; Koch, M.; Fischer, S.; Pfisterer, D. Critical Infrastructure Surveillance Using Secure Wireless Sensor Networks. J. Sens. Actuator Netw. 2015, 4, 336-370. [CrossRef]

38. Ouadou, M.; Zytoune, O.; El Hillali, Y.; Menhaj-Rivenq, A.; Aboutajdine, D. Energy Efficient Hardware and Improved Cluster-Tree Topology for Lifetime Prolongation in ZigBee Sensor Networks. J. Sens. Actuator Netw. 2017, 6, 22. [CrossRef] 


\section{П.В. Галкін}

Харківський національний університет радіоелектроніки

Адаптивні концепції та оптимізаційний підхід до проектування тестових стендів та вузлів для бездротових сенсорних мережс

Об'єктом дослідження є вузли та тестові макети для бездротових сенсорних мереж. У статті проаналізовано вимоги до вузла бездротової сенсорної мережі та тестової платформи. Мета дослідження - розробити адаптивну конщепцію та оптимізаційний підхід до проектування тестових стендів та вузлів для бездротових сенсорних мереж. Запропоновано апаратні компоненти для побудови тестової платформи для бездротових сенсорних мереж. Тестова платформа для бездротових сенсорних мереж була розроблена як друкована плата. В результаті запропоноване рішення можна використовувати для прототипу, а також розгортати та масштабувати бездротову сенсорну мережу. У вузлах бездротової сенсорної мережі пропонується використовувати модулі СС2530. Були проаналізовані також периферійні можливості СС2530. В якості одного з оптимізаційних підходів до проектування бездротової сенсорної мережі запропоновано структуру вузла. Також приведений аналіз проектування вузлів та області використання. Розроблені підходи можуть бути використані для будь-якого застосування бездротової сенсорної мережі.

Ключові слова: Адаптивна концепчія; СС2530; Розробка тестових стендів; Проектування вузлів; Інтернет речей; Бездротові сенсорні мережі.

\section{П.В. Галкин}

Харьковский национальный университет радиоэлектроники

Адаптивні Адаптивные концепции и оптимизационный подход к проектированию тестовых стендов и узлов для беспроводных сенсорных сетей

Объектом исследования являются узлы и тестовые макеты для беспроводных сенсорных сетей. В статье проанализированы требования к узлу беспроводной сенсорной сети $u$ тестовой платформы. Цель исследования - разработать адаптивную концепџию $u$ оптимизаџионный подход к проектированию тестовых стендов и узлов для беспроводных сенсорных сетей. Предложено аппаратные компоненты для построения тестовой платформы для беспроводных сенсорных сетей. Тестовая платформа для беспроводных сенсорных сетей была разработана как печатная плата. В результате предложенное решение можно использовать для прототипа, а также разворачивать и масштабировать беспроводную сенсорную сеть. В узлах беспроводной сенсорной сети предлагается использовать модули СС2530. Были проанализированы также периферийные возможности СС2530. В качестве одного из оптимизачионных подходов к проектированию беспроводной сенсорной сети предложена структура узла. Также приведен анализ проектирования узлов и области использования. Разработанные подходы могут быть использованы для любого применения беспроводной сенсорной сети.

Ключевые слова: Адаптивная концепџия; СС2530; Разработка тестовых стендов; Проектирование узлов Интернет вещей; Беспроводные сенсорные сети.

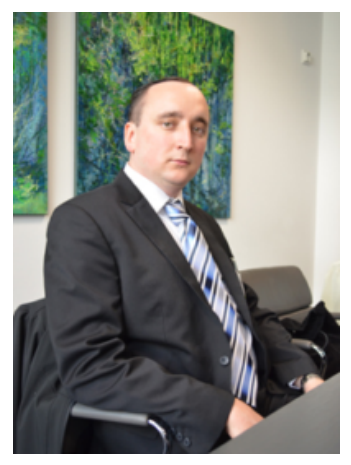

Pavlo Galkin, Ukraine, Senior Lecturer from the Kharkiv National University of Radio Electronics, Design and Operation of Electronic Devices Department (Nauka Avenue, 14, Kharkiv, Kharkiv region, 61000), key research area is Research and development of Wireless sensor network, Industrial automation, Embedded System, IoT and IIoT solution. 